\title{
The first data on pottery technology of early nomads in the Northern Pontic Steppe
}

\begin{abstract}
The main innovation in the Northern Pontic region in the Early Iron Age during 10-8 cc. $\mathrm{BC}$ was the appearance of iron processing technology and the manufacture of iron products during this time. One of the indicators of this innovation is the changes in the pottery manufacture also. The pottery is characterized by a high quality, thinness of walls, polished surface ornamented by inlay of white paste. The appearance of such "Thracian" ceramics among local inhabitants is a marker of the Early Hallstatt culture influencing. Ceramics samples of this period founded in settlement complexes of the Subitiv (Belogrudovskaya culture) and Hligeni II (Sakharna culture) were investigated by XRF analysis, SEM-EDS analysis, in the thin sections and micro-tomography for reconstruction of ceramic technology. The first preliminary investigations allow determining to determine the features in technology of different ceramic types.
\end{abstract}

Keywords: early hallstatt culture, early nomads in the northern pontic steppe, pottery technology, early iron age, sakharna culture, xrf analysis, sem-eds analysis, mct-tomography
Volume I Issue 5 - 2017

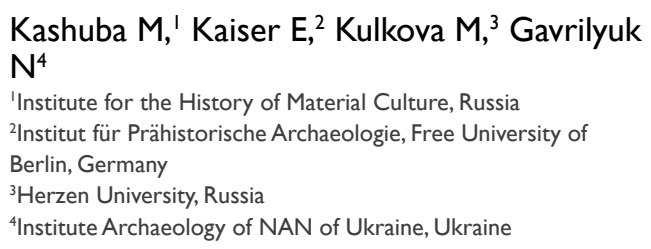

Correspondence: Kashuba M, Institute for the History of Material Culture, Russia, Email kulkova@mail.ru

Received: May 26, 2017 | Published: September 06, 2017

\section{Introduction}

In the period of 10 th- 8 th cc. $\mathrm{BC}$ the significance changes in cultural-historical processes occurred in the Northern Pontic region, when the agricultural- stock rising economic form was superseded by cattle breeding and nomadic style of the life. The main innovation in this region was the appearance of iron processing technology and the manufacture of iron products during this time. ${ }^{1}$ One of the indicators of this innovation is the changes in the pottery manufacture also. The pottery is characterized by a high quality, thinness of walls, polished surface ornamented by inlay of white paste. The appearance of this type of ceramics is a marker of the early Hallstattian (carpathodanubian) cultures. The carriers of Hallstattian cultures migrated from the Middle and Low Danube region towards in the eastern forest steppe zone of the Black Sea Region.

The vessels so-called Thracian groups from interments of PreScythian Chernogorovsk and Novocherkassk groups of early nomads located in the steppe zone of the Northern Pontic have very distinctive features in comparison to the local ceramics. The numerous collections of the "Thracian" polished ceramics from the steppe zone of the 9th beginning of 8th cc. BC consists of the squat cups with the bend corolla and curved throat, cup-shaped vessels and "amphorae" (vessels with cylindrical and conical throats) with curved throat. The surfaces of these vessels are covered by wide ornamented strips. The ornamentation was carried out in the curved technique with prints of toothed, "S", "W" and round stamps. There are prevailed the filling in geometric figures (triangles, rhosmbs) by the oblique lines. The ceramic paste was well mixed; the polishing is olive-gray, brown and gray color of good quality. The carved and stamped ornamentations are filled by inlay of white paste.

In the collection of vessels from the steppe Northern Pontic burials of 9th - the first half of 7 th $\mathrm{cc}$. BC there are determined several ceramic groups, which are different on their origin. ${ }^{2,3}$ The local and unoriginal components of "early nomadically" pottery (including "Thracian" ware) and the classification and typology of the polished ceramics from steppe Pre-Scythian burials have been considered. ${ }^{4-7}$ These investigations are important but they are insufficient for the understanding of development between the early nomads and sedentary societies. In this case we would like to consider the differentiation inside "Thracian" (Saharna), "forest steppe" (Chernolessk, Zhabotin) cultures and other groups in the circle of cultures with polished ceramics in steppe zone; to establish the influence of new cultural traditions on the local cultures; to determine the borrowing or conservation of technologies during the period of changes in economic organization of society. The question about ways of a penetration of "Thracian" ceramics toward steppe Northern Pontic has been not resolved yet. It could be both the trade-exchange contacts and ethno-cultural connections. Ceramics in this case are a unique and the most informative materials for resolving of such kind questions. The important task is investigations of pottery technology and the determination of clay raw sources for ceramic moulding in this region.

The burials, in which the polished pottery similar to Saharna ceramics had been found, are located close each other in the Northern Black Sea Coast and in the lower flows of rivers. Few burials were found in the forest steppe zone. The meridional vector (along the meridians) of distribution of burials with "Thracian" ceramics in the Northern Black Sea Region was traced for the period of the 9th - beginning of 8th cc. BC. According to recent dates the beginning of early Hallstattian culture is concerned to the end of the 11th - the frontier of the 10th/9th cc. BC. The late dates are the beginning of 8 th c. BC. ${ }^{8}$

Several polished vessels (cups, cup-shaped vessels with cylindrical throat, jugs and "amphora" with cylindrical and conical throats) from burials of 8 th - the first half of 7th cc. BC located in the steppe zone of the Northern Black Sea Coast are belonged to the Sholdaneshti (Basarabi-Sholdaneshti) culture. The Sholdaneshti culture was developed in the Middle Dniester river region. There were found the archaeological monuments of this culture in the eastern part of this region. In the other part there were just archaeological materials 
connected with the contacts, import (ceramics, individual products) and imitations. The Sholdaneshti culture and the Late Saharna culture existed together during the short period from the beginning first quarter of the 8th c. BC. The upper framework of Sholdaneshti culture is dated to the middle of the $7^{\text {th }} \mathrm{c}$. BC..$^{9,10}$ The main decorative motifs of this type of ceramics are flutes and cone-shaped overlays. The vessels are moulded from mixed clay pastes and they are polished by the good looking black covering. The burials containing the pottery similar to the pottery of the Basarabi-Sholdaneshti culture are scattered and they are wide developed in the steppe and forest steppe areas of the Northern Black Sea region. An intensive occupation of the steppe and southern forest steppe areas and the latitudinal distribution of "Thracian" cultures were registered during the 8th and in the first half of the 7th cc. BC.

Samples of pottery from settlement complexes were collected for the first researches of ceramic technology. It is the vessels of Belogrudovsk culture from the Subotiv settlement and the vessels of Saharna culture from Hligeni II city-site. The pottery from settlements is a reliable indicator characterizing the economic structure of life. Therefore such investigation allows understanding the process of ceramic manufacture generally. In the case of pottery from burials it is difficult because we deal with unique exemplars, which were produced in one copy sometimes. The Subotiv settlement is situated on the Shore of Suboti River in Cherkassy district of Ukraine. The Belogrudovskaya culture was formed on the base of the KomarovskoTishinezkaya culture which penetrated in this region from SouthernWestern Volin' through Pripyat' tributaries. The Hligeni II city-site is situated on the left upper terrace and a narrow canyon valley of the Chornaya River (the right tributary of Dniester). The early Hallstatt horizon on this site belongs to the Saharna culture and is dated by the end of the 11 th to the first quarter of $8^{\text {th }} \mathrm{c}$. BC. ${ }^{11}$

The pottery of Belogrudovskaya stage is presented by tulipshaped vessels without ornamentation or with smooth or rare finger impressions on a shoulder level. There are punctures under corolla. Big round-shouldered vessels with cylindrical low neck were found also. The surface of the vessels was smoothed by hand but sometimes it was polished. Squat cups with flat or round bottom, with a cylindrical throat have sometimes the toothed ornamentation in the upper part of body. The decoration consists of horizontal strips and zigzags. Cups, bowls were polished by light black, gray and brownish cover. One cup has the triple cone overlays. The similar cups are known in the settlements of Srubna culture in the Low Dnieper region. ${ }^{12,13}$ The appearance of black polished ceramics with the specific inner surface and the decoration and high banks ornamented by vertical combing in the Belogrudovsk culture can be connected with influence of Hallstattian cultures.

On the base of technological features and functional purposes the Saharna pottery is divided on the "cooking" and polished "tableware's". The features of ceramic assemblages of this culture are the numerous of ritual forms (small vessels, vessels on the legs, pyxis) and there was a special manufacture of funeral pottery. The four types of vessels were determined: straight-walled, barrel-shaped, weakly profiled and tulip-shaped. The main types of cooking and tablewares from Hligeni II city-site belongs to Saharna culture and is similar with pottery of the early Hallstattian horizon containing the traced and printed ceramics from the Carpathian-Danubian region. ${ }^{11}$

The complex analytic methods were applied for investigations of the ceramic technology: the composition of ceramic pastes, the conditions and temperature of firing. The technology of pottery making was studied in thin sections. The SEM-EDS analysis was applied for geochemical mapping of pottery surface. The mineralogical composition was determined with help of microprobe analysis. The geochemical composition of samples was investigated by XRF analysis. The high resolution 3D computed microtomography (micro CT) was used to visualize and characterize the internal structure of ceramic samples. $3 \mathrm{D}$ void visualization allowed to determine the pores occurred during burning of different types of organics and to calculate the porosity. These researches were provided on the base of "Geomodel" Centre of State St. Petersburg University. The results of investigations allowed determining the features in technology of different ceramic types.

The first preliminary investigations give the possibility to determine that the composition of ceramic pastes of samples of Belogrudovskaya culture differs from Saharna ceramics (Hligeni II site). The ceramic paste for pottery from Hligeni II site was predominantly moulded from lean clay of smectite composition. Sand, crushed lime rocks (chalk, limestone), grog (crushed ceramics of different composition) were added as a temper. The pottery was fired in the oven in reduce atmosphere at the temperature of 700 $850^{\circ} \mathrm{C}$. For Belogrudovskaya pottery the ceramic paste consists of the fat clay of smectite composition. As a temper the crushed intrusive rocks (granite andesite) were used. Sometimes, well-rounded sand and grog were used as a temper. The firing was in an oven, at the temperature about $650-700^{\circ} \mathrm{C}$, long-term, in the reducing conditions. The 3D micro CT allowed to reconstruct the inclusions of burnt out organics in clay as aquatic plants (algae). So, the main source of clay for pottery moulding could be alluvial, floodplain deposits of rivers. The chemical composition of ceramics showed that the sources of clay raw materials and paste recipes of pottery from the Hligeni II and Subotiv had significant differences. The ceramics from the Hligeni II site are enriched by such chemical components as ( $\mathrm{Ba}, \mathrm{V}, \mathrm{MnO}, \mathrm{MgO}$, $\left.\mathrm{P}_{2} \mathrm{O}_{5}\right)$, but the ceramics from Subotiv site by $\left(\mathrm{Al}_{2} \mathrm{O}_{3}, \mathrm{SiO}_{2}, \mathrm{Fe}_{2} \mathrm{O}_{3}\right)$. The ceramic paste composition of Saharna culture is more homogeneous then the ceramic paste of Belogrudovskaya culture. The samples of Belogrudovskaya culture have more variations in their composition and probably they have differentiation in clay raw sources.

It is interesting to note that one of the samples from Hligeni II site has been considered as import according to archaeological data. This is black polished vessel ornamented by flutes and it has differences from other vessels of the collection. On the data of the chemical analysis and thin section analysis the technology of this pottery has not differentiations from other ceramics of this group. So, it is possible that this vessel is a skillful imitation of the early Hallstattian pottery from local raw materials on this site or this vessel was moulded by "Hallstattian" potter from local materials.

At present the investigations of pottery technology and identification of characteristic features of ceramics that can be used for determination of syncretic vessels, the mixing of pottery traditions, the influence of one tradition on the other, borrowing of technological receptions are continuing.

\section{Acknowledgements}

This article is supported by the Volkswagen Foundation, project № 90216.

\section{Conflict of interest}

Author declares there is no conflict of interest in publishing the article. 


\section{References}

1. Kashuba MT. Iron: the transition to the Early Iron Age in the East Carpathian region. Russian Archaeological Yearbook No. 3, Russia; 2013. p. 233-257.

2. Gavrilyuk NA. Local and borrowed components in the Cimmerian culture (Based on ceramics). Herald of Ancient History. 1999;1:85-97.

3. Gavrilyuk N. The history of the study of early iron ceramics and archaeological materials. Ukrainian ceramological Journal. 2004;1:25-30.

4. Gavrilyuk NA. Polished ceramics of the pre-Scythian steppe burials In: Monuments of ancient cultures of the Northern Black Sea Coast. Scientific thought, Ukraine; 1979. p. 20-41.

5. Bruyako IV. Early nomads in Europe (10th- 5th cc. BC). Stratum plus, Moldova; 2005. p. 358.

6. Makhortych SV. Cimmerian of the Northern Pontic region. Bibliotheca Vita Antiqua, Ukraine; 2005. p. 380.

7. Daragan MN, Podobed VA. Zhabotinskyi horizon and Chernogorovskaya culture: chronological correlations. Black Sea Coastal Region in ancient and early medieval times: Collection of scientific works dedicated to the $65^{\text {th }}$ anniversary of Prof Kopylov VP. Russia; 2013. p. 32-45.

8. Kašuba M. Die ältesten Fibeln im Nordpontus. Versuch einer Typologie der einfachen Violinbogenfibeln im südlichen Mittel, Süd- und Südosteuropa, Eurasia Antiqua. 2008a;14S:193-231.

9. Kašuba M. Zur Entstehung der Basarabi-Kultur in Osteuropa. Scripta praehistorica varia in honorem Biba Teržan, Slovenia; 2007. p. 369-380.

10. Kaşuba M. Materiale ale culturii Şoldăneşti în bazinul Nistrului de Mijlociu observaţii preliminare. Tyragetia. 2008b;2(17):37-50.

11. Goltseva NV, Kashuba MT, Hligeni II. Multilayered monument of Middle Dniester Region (Excavation materials 1978-79 and 1989-90). Tiraspol Mako. 1995;5:272 .

12. Grakov BN. Early Iron Age. Moscow State University, Russia; 1977. p. 235 .

13. Terenozhkin AI. Cimmerian. Scientific thought, Ukraine; 1976. p. 220. 